\title{
Pengaruh Return on Assets, Earnings per Share dan Book Value per Share terhadap Harga Saham
}

\author{
Dimas Saputro \\ Universitas Islam Batik, Surakarta \\ e-mail:dmazahong6@gmail.com
}

\begin{abstract}
This study aims to obtain results about the effect of the variable Return on Assets on stock prices, Earnings per Share on stock prices, and Book Value per Share on stock prices, the subject of this study are 45 issuers included in the LQ45 on the Indonesian stock exchange and always included LQ45 from 2014 to 2017, using variable ROA, EPS BVPS and stock prices, data are recorded and analyzed by multiple linear regression analysis, and the results show that partially Return on Assets, Earnings per Share and Book Value per Share one in one partial positive and significant effect on stock prices, and simultaneously Return on Assets, Earnings per Share and Book Value per Share have a significant effect on stock prices, meaning that it can be interpreted that the variables ROA, EPS, and BVPS affect stock prices
\end{abstract}

Keywords: ROA, EPS, BVPS, Stock Price.

\section{PENDAHULUAN}

Investasi termasuk peran penting untuk meningkatkan pertumbuhan ekonomi suatu negeri, dalam berinvestasi. Salah satu caranya adalah melalui pasar modal, dan saham termasuk dalam pasar modal dan sangat popular di kalangan investor. Hal ini karena terdapat berbagai kepraktisan kemudahan dan keuntungan dalam berinvestasi pada saham perusahaan, diantaranya adalah dana yang diinvestasikan oleh investor cukup liquid karena bisa ditarik setiap saat, dan pilihan terbaik untuk berinvestasi lewat pasar modal adalah menginvestasikan dananya di dalam perusahaan LQ45. Pertimbangan ini karena LQ45 dapat dikategorikan baik sebab perusahaan yang tergabung dalam LQ45 memiliki likuiditas tinggi yang dipilih melalui beberapa kriteria pemilihan yang sudah terpercaya.

Dalam menganalisa harga saham, para investor maupun trader saham mengunakan beberapa pertimbangan perhitungan dan analisis, seperti analisis fundamental, analisis tehnikal dan analisis sentiment dan analisis lain seperti kondisi sosial politik, kebijakan perekonomian makro, bandarmologi dan lain lain.

Menurut Muammarsyah (2012), resiko invetasi yang ditanggung oleh investor akan semakin kecil bila kinerja perusahaan dinilai baik, karena bila kinerja perusahaan tersebut baik akan bisa meningkatkan permintaan investor untuk memiliki saham emiten tersebut. Kinerja perusahaan bisa dilihat dari fundamental perusahaannya, dan dalam fundamental perusahaan terdapat rasio-rasio keuangan yang dapat digunakan untuk menganalisis harga saham, seperti rasio likuiditas, rasio aktifitas, rasio solvabilitas, rasio profitabilitas dan rasio pasar.

Hanafi (2008) menyatakan bahwa ROA adalah rasio profitabilitas yang mengukur kemampuan perusahaan menghasilkan laba dengan menggunakan total asset (kekayaan) yang dimiliki perusahaan setelah disesuaikan dengan biaya-biaya untuk menandai asset tersebut. Sambelay et al. (2017) menemukan hasil bahwa Return on Asset (ROA) secara parsial terdapat pengaruh positif dan 
signifikan terhadap harga saham. Hal ini dikarenakan investor menilai ROA yang tinggi berarti bahwa perusahaan bisa mengelola manajemen nya dengan baik aktiva yang dimiliki agar terus bertambah dengan lebih cepat; dengan terus bertambahnya aktiva perusahaan dengan cepat maka akan semakin besar nilai perusahaan tersebut.

Fahmi (2012) menyatakan Earning per Share (EPS) merupakan keuntungan yang diberikan untuk para pemegang saham dari setiap lembar saham yang dimiliki dan dapat dihitung dengan membagi laba per lembar saham dengan jumlah saham yang beredar. Wati (2018) menemukan hasil bahwa EPS secara parsial memiliki pengaruh yang signifikan terhadap harga saham. Hal ini dikarenakan investor menilai EPS yang tinggi bisa memungkinkan pembagian deviden yang lebih besar, dengan begitu banyak investor yang berminat untuk membeli harga saham tersebut. Dengan banyaknya permintaan untuk memiliki saham tersebut akan otomatis bias meningkatkan harga saham.

Book Value per Share (BVPS) adalah rasio yang digunakan untuk membandingkan ekuitas pemegang saham dengan jumlah saham yang beredar (Fahmi, 2012). Dengan kata lain, rasio ini digunakan untuk mengetahui berapa jumlah uang yang akan diterima oleh pemegang saham bila suatu perusahaan dilikuidasi atau jumlah uang yang dapat diterima oleh pemegang saham apabila semua aktiva (aset) perusahaan dijual sebesar nilai bukunya. Hasil penelitian Sumarno dan Gunistiyo (2017) menemukan hasil bahwa BVPS secara parsial terdapat pengaruh positif dan signifikan terhadap harga saham.

Teori utama yang digunakan sebagai landasan atau dasar lahirnya teori-teori dari suatu variabel. Dalam penelitian ini berdasarkan teori yang salah satunya adalah stakeholder theory yang mengemukakan bahwa perusahaan adalah entitas yang beroperasi tidak hanya untuk kepentingannya perusahaan itu sendiri, namun juga harus menghasilkan manfaat kepada seluruh stakeholder ataupun shareholder. Hal ini karena kelangsungan hidup suatu perusahaan didukung oleh stakeholder dan shareholder
(Ghozali \& Chariri, 2007). Pemegang saham, kreditor, konsumen, supplier, pemerintah, masyarakat, analis, dan pihak lain merupakan kelompok stakeholder yang menjadi bahan pertimbangan perusahaan mengungkapkan atau tidak suatu informasi yang berada dalam laporan keuangan perusahaan. Semua stakeholder mempunyai hak memperoleh informasi tentang aktivitas perusahaan.

Teori kedua dalam penelitian ini adalah Signaling Theory atau sinyal yang menurut Conelly et al. (2011) merupakan konsep dimana pihak pemberi informasi dapat memilih apa dan bagaimana informasi akan ditampilkan dan pihak penerima informasi dapat memilih bagaimana menginpretasikan informasi yang diterima. Perusahaan yang baik dapat membedakan dirinya dengan perusahaan yang tidak baik dengan mengirimkan sinyal yang dapat dipercaya (credible signal) mengenai kualitasnya ke pasar modal (Spence, 1973). Signalling Theory merupakan sinyal-sinyal informasi yang dibutuhkan oleh investor untuk mempertimbangkan dan menentukan apakah para investor akan menanamkan sahamnya ataupun tidak kepada perusahaan yang bersangkutan.

Penelitian ini bertujuan menganalisis pengaruh Return on Asset (ROA), Earnings per Share (EPS) dan Book Value per Share (BVPS) terhadap harga saham, Dengan adanya hasil penelitian ini bisa diambil manfaat untuk para investor ataupun trader untuk bahan pertimbangan mengambil keputusan dalam menanamkan investsinya ataupun untuk keputusannya dalam jual beli saham di pasar modal.

\section{Harga Saham}

Menurut Sapto (2006), saham adalah surat berharga yang merupakan instrumen bukti kepemilikan atau penyertaan dari individu ataupun institusi di dalam suatu perusahaan. Sedangkan menurut istilah umum, saham merupakan bukti penyertaan modal dalam suatu kepemilikan saham perusahaan.

Harga saham adalah harga yang dibentuk dari interaksi antara para penjual dan pembeli saham yang dilatarbelakangi oleh 
harapan mereka atas keuntungan perusahaan. Harga saham penutupan yaitu harga yang diminta oleh penjual atau harga perdagangan terakhir suatu periode. Harga saham merupakan harga atau uang yang bersedia dikeluarkan untuk memperoleh saham (Widoatmodjo, 2009).

\section{Return on Assets}

Hanafi (2008) menyatakan Return on Asset (ROA) adalah rasio profitabilitas yang mengukur kemampuan perusahaan dalam menghasilkan laba dengan menggunakan total asset (kekayaan) yang dimiliki perusahaan setelah disesuaikan dengan biaya -biaya untuk menandai asset tersebut. Dengan mengetahui nilai rasio ini bisa melihat prospek perkembangan suatu perusahaan tersebut.

ROA yang tinggi memberi arti bahwa perusahaan bisa melakukan manajemen dengan baik atas aktiva yang dimiliki sehingga terus bertambah dengan lebih cepat. Dengan terus bertambahnya aktiva milik perusahaan tersebut dengan cepat, maka akan semakin besar nilai perusahaan tersebut.

\section{Earnings per Share}

Fahmi (2012) menyatakan Earning per Share (EPS) merupakan keuntungan yang dapat diberikan untuk para pemegang saham dari setiap lembar saham yang dimiliki dan dapat dihitung dengan membagi laba per lembar saham dengan jumlah saham yang beredar. Dengan kata lain, EPS merupakan rasio yang dapat mencerminkan kemampuan suatu perusahaan dalam penghasilan laba untuk setiap lembar saham yang beredar.

Menurut Darmadji dan Fakhrudin (2011), investor menilai EPS yang tinggi bisa memungkinkan pembagian deviden yang lebih besar, tergantung kebijakan manajemen perusahaan tersebut.

\section{Book Value per Share}

Book Value per Share (BVPS) adalah rasio yang digunakan untuk membandingkan ekuitas pemegang saham dengan jumlah saham yang beredar. Dengan kata lain, rasio ini digunakan untuk mengetahui berapa jumlah uang yang akan diterima oleh pemegang saham apabila suatu perusahaan dilikuidasi, atau jumlah uang yang dapat diterima oleh pemegang saham apabila semua aktiva (aset) perusahaan dijual sebesar nilai bukunya. Selain itu, nilai BVPS ini bisa digunakan untuk para investor untuk menilai harga wajar suatu perusahaan untuk tiap lembar sahamnya.

\section{Hipotesis}

Return on Assets adalah rasio yang menunjukkkan kemampuan manajemen perusahaan dalam memperoleh laba dengan menggunakan total kekayaan yang dimiliki perusahaan yang bersangkutan. Hasil penelitian Sambelay et al. (2017) menemukan hasil bahwa Return on Asset secara parsial terdapat pengaruh positif dan signifikan terhadap harga saham. Berdasarkan hasil penelitian tersebut, maka dimunculkan hipotesis pertama dalam penelitian ini, yaitu:

H1: Return on Assets berpengaruh positif terhadap Harga Saham.

Earning per Share diartikan sebagai keuntungan yang diberikan untuk para stakeholder dari tiap lembar yang dimiliki dan dapat dihitung dengan membagi laba dengan jumlah saham yang beredar. Hasil penelitian Wati (2018) menemukan hasil bahwa earning per share secara parsial terdapat pengaruh positif dan signifikan terhadap harga saham. Berdasarkan hasil penelitian tersebut, maka dimunculkan hipotesis kedua dalam penelitian ini, yaitu:

H2: Earning per Share berpengaruh positif terhadap Harga Saham.

Book Value per Share (BVPS) adalah rasio yang digunakan untuk membandingkan ekuitas pemegang saham disbanding dengan jumlah saham yang beredar. Dengan kata lain, rasio ini digunakan untuk mengetahui berapa jumlah uang yang akan diterima oleh para stakeholder bila suatu perusahaan dilikuidasi atau jumlah uang yang dapat diterima oleh stakeholder apabila semua asset yang masih dimiliki perusahaan dijual dan di kurangi hutang perusahaan. Hasil penelitian Sumarno dan Gunistiyo (2017) menemukan hasil bahwa Book Value per Share secara parsial 
memiliki pengaruh positif dan signifikan terhadap harga saham. Berdasarkan hasil penelitian tersebut, maka dimunculkan hipotesis ketiga dalam penelitian ini, yaitu:

H3: Book Value per Share berpengaruh positif terhadap Harga Saham.

\section{Kerangka Pemikiran}

Dalam penelitian ini berfokus untuk mengetahui pengaruh Return on Assets (ROA), Earnings per Share (EPS) dan Book Value per Share (BVPS) terhadap harga saham. Berdasarkan fokus tersebut, maka dapat digambarkan kerangka pemikiran dari penelitian ini seperti terlihat dalam Gambar 1.

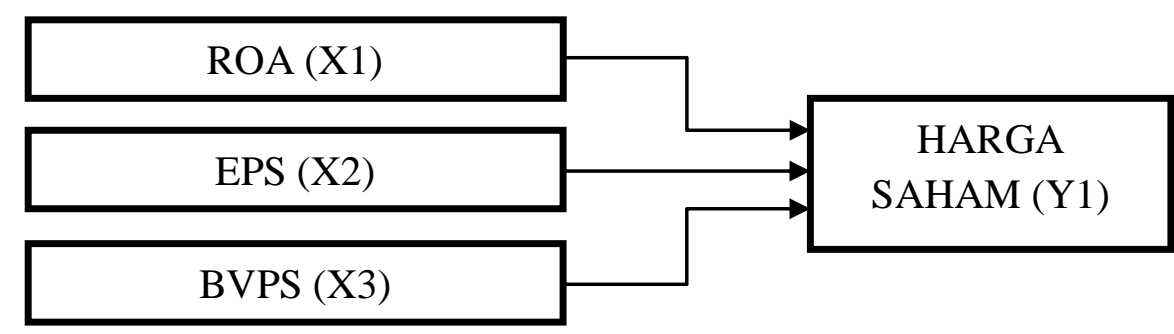

Gambar 1. Kerangka Pemikiran

Tabel 1. Pemilihan Sampel

\begin{tabular}{|c|c|c|}
\hline No & Kriteria & Jumlah \\
\hline 1. & $\begin{array}{l}\text { Perusahaan yang terdaftar di Bursa Efek Indonesia dan termasuk dalam } \\
\text { LQ45 tahun } 2017\end{array}$ & 45 \\
\hline 2. & Perusahan yang baru IPO setelah tahun 2014 & -1 \\
\hline 3. & Perusahaan yang pernah mengalami kerugian dari tahun $2014-2017$ & -7 \\
\hline 4. & Jumlah Sampel perusahaan & 37 \\
\hline 5. & Tahun Observasi & 4 \\
\hline 6. & Jumlah Observasi & 148 \\
\hline \multirow[t]{2}{*}{7} & Data Outlier & -36 \\
\hline & Jumlah Sampel & 112 \\
\hline
\end{tabular}

Sumber: Data Sekunder Diolah, 2019

\section{METODE PENELITIAN}

Metode penelitian yang dilakukan adalah penelitian kuantitatif karena data penelitian berupa angka-angka dan analisis menggunakan statistik. Jenis data sekunder yang diambil dari laporan keuangan yang di publikasikan lewat website IDX.

Populasi penelitian ini sebanyak 45 perusahaan yang terdaftar dalam Bursa Efek Indonesia dan termasuk dalam LQ45 selama periode 2014-2017. Teknik pengambilan sampel menggunakan purposive sampling dengan kriteria:

1. Perusahan yang terdaftar di bursa efek Indonesia dan termasuk dalam LQ45 tahun $2014-2017$.

2. Perusahaan yang sudah IPO sebelum tahun 2014.
3. Perusahaan yang tidak pernah mengalami kerugian dari tahun $2014-2017$.

Berdasarkan kriteria-kriteria tersebut, terpilih sampel sebanyak 37 perusahaan. Proses pemilihan sampel ditunjukkan dalam Tabel 1.

Penelitian ini menggunakan tiga variabel independen dan satu variabel dependen. Pengukuran variabel dilakukan menggunakan rumus yang dirangkum dalam Tabel 2.

\section{HASIL ANALISIS \\ Analisis Deskriptif}

Hasil uji statistik deskriptif seperti terlihat dalam Tabel 3 dimana nilai rata-rata (mean) masing-masing variabel menunjukkan hasil yang positif. ROA, EPS, BVPS, dan 
Harga Saham menunjukkan nilai rata-rata (mean) yang lebih besar dari standar deviasinya. Hal ini menunjukkan data tersebut bersifat stabil, merata, dan tidak menyimpang.

\section{Uji Asumsi Klasik}

Uji asumsi klasik digunakan untuk mengetahui ada tidaknya normalitas residual, multikolinieritas, autokolerasi, dan heteroskedastisitas. Hasil uji asumsi klasik ditunjukkan dalam Tabel 4 sampai Tabel 7.

\section{Hasil Uji Normalitas Residual}

Berdasarkan hasil dalam Tabel 4 diperoleh bahwa nilai signifikansi (Asymp. Sig 2-tailed) sebesar 0,200, sementara Standar normalitas data adalah lebih besar dari 0,05. Dengan demikian, karena nilai signifikansi lebih besar $(0,200>0,05)$ maka nilai residual dinyatakan terdistribusi dengan normal.

\section{Hasil Uji Multikolinieritas}

Dalam menguji penelitian ini digunakan Tolerance Value (TV) dan Variance Inflation
Factor (VIF). Berdasarkan hasil di dalam Tabel 5 diperoleh bahwa nilai TV dari ketiga variabel lebih dari 0,10 dan VIF kurang dari 10, maka dapat disimpulkan bahwa tidak terjadi multikolinieritas antar variabel bebas.

\section{Hasil Uji Autokorelasi}

Berdasarkan hasil dalam Tabel 6 di peroleh bahwa nilai DU $<$ DW < 4-DU, sehingga dinyatakan tidak terjadi autokolerasi dalam model regresi dari penelitian ini.

\section{Hasil Uji Heterokedastisitas}

Dalam uji ini digunakan korelasi Spearman,s rho. Pengujian menggunakan tingkat signifikansi 0,05 dengan uji 2-sisi. Dari hasil output di Tabel 7 terlihat bahwa korelasi antar variabel dengan Unstandardized Residual memiliki nilai signifikansi (sig 2 tailed) lebih dari 0,05. Dengan demikian dapat disimpulkan bahwa tidak terjadi masalah heteroskedastisitas dalam model regresi penelitian ini.

Tabel 2. Pengukuran Variabel Penelitian

\begin{tabular}{cll}
\hline No & \multicolumn{1}{c}{ Variabel } & \multicolumn{1}{c}{ Rumus Pengukuran } \\
\hline 1. & Harga Saham & $\begin{array}{l}\text { Harga pasar saham terbentuk melalui mekanisme } \\
\text { permintaan dan penawaran di pasar modal } \\
\text { (Sartono, 2001) }\end{array}$ \\
\hline R. Return on Assets (ROA) & $\frac{\text { Laba Bersih }}{\text { Total Asset }} \times 100 \%$ \\
& (Titman \& Wessels, 1988) \\
\hline 3. $\quad$ Earnings per Share (EPS) & EPS $=\frac{\text { Laba Bersih }}{\text { Jumlah lembar saham }} \times 100 \%$ \\
& & (Titman \& Wessels, 1988) \\
\hline 4. Book Value per Share (BVPS) & BV $=\frac{\text { Total Modal }}{\text { Jumlah lembar saham }}$ \\
& & (Brealey \& Myers, 2008) \\
\hline
\end{tabular}

Sumber: Data Sekunder Diolah, 2019

Tabel 3. Hasil Descriptive Statistics

\begin{tabular}{lcrrrc}
\hline & N & \multicolumn{1}{c}{ Minimum } & \multicolumn{1}{c}{ Maimum } & Mean & Stdev \\
\hline ROA & 112 & -.14895 & 3.32141 & 1.3331438 & .68993489 \\
EPS & 112 & 2.40841 & 6.80694 & 4.1588621 & .97210688 \\
BVPS & 112 & 3.27000 & 8.03926 & 5.6550496 & .99240839 \\
HARGA SAHAM & 112 & 4.30915 & 9.20973 & 6.3235124 & .95127779 \\
Valid N (listwise) & 112 & & & & \\
\hline
\end{tabular}

Sumber: Data Sekunder Diolah, 2019 
Tabel 4. Hasil Uji Normalitas (One-Sample Kolmogorov-Smirnov Test)

\begin{tabular}{cccc}
\hline Variabel & Asymp. Sig. (2-tailed) & Standar & Keterangan \\
\hline $\begin{array}{c}\text { Unstandardized } \\
\text { Residual }\end{array}$ & 0,200 & $>0,05$ & Data Normal \\
\hline
\end{tabular}

Sumber: Data Sekunder Diolah, 2019

Tabel 5. Hasil Uji Multikolinieritas (VIF)

\begin{tabular}{lccccc}
\hline \multicolumn{1}{c}{ Variabel } & Tolerance & Standar & VIF & Standar & Keterangan \\
\hline ROA & 0,643 & $>0,10$ & 1,554 & $<10$ & Non Multikolinieritas \\
EPS & 0,141 & $>0,10$ & 7.096 & $<10$ & Non Multikolinieritas \\
BVPS & 0,137 & $>0,10$ & 7.314 & $<10$ & Non Multikolinieritas \\
\hline
\end{tabular}

Sumber: Data Sekunder Diolah, 2019

Tabel 6. Hasil Uji Autokorelasi

\begin{tabular}{cccc}
\hline Du & Durbin-Watson & 4-Du & Keterangan \\
\hline $1,7415<$ & 1,796 & $<2,252$ & Tidak terjadi \\
& Autokorelasi \\
\hline
\end{tabular}

Sumber: Data Sekunder Diolah, 2019

Tabel 7. Hasil Uji Heterokedastisitas

\begin{tabular}{lccc}
\hline \multicolumn{1}{c}{ Variabel } & Sig. (2-tailed) & Standar & Keterangan \\
\hline ROA & 0,722 & $>0,05$ & Bebas Heterokedastisitas \\
EPS & 0,707 & $>0,05$ & Bebas Heterokedastisitas \\
BVPS & 0,679 & $>0,05$ & Bebas Heterokedastisitas \\
\hline
\end{tabular}

Sumber: Data Sekunder Diolah, 2019

Tabel 8. Hasil Regresi Linier Berganda

\begin{tabular}{lcc}
\hline \multicolumn{1}{c}{ Model } & B & Arah Pengaruh \\
\hline Constant & 1,840 & - \\
ROA & 0,243 & Positif \\
EPS & 0,603 & Positif \\
BVPS & 0,292 & Positif \\
\hline
\end{tabular}

Sumber: Data Sekunder Diolah, 2019

\section{Analisis Regresi Berganda}

Berdasarkan hasil yang terangkum dalam Tabel 8, maka diperoleh persamaan regresi berganda:

$$
\begin{aligned}
\mathrm{Y}= & 1,840+0,243 \mathrm{ROA}+0,603 \mathrm{EPS}+ \\
& 0,292 \mathrm{BVPS}+\mathrm{e}
\end{aligned}
$$

Dari persamaan regresi itu, dapat dijelaskan sebagai berikut:

- Konstanta sebesar 1,840 menyatakan bahwa jika nilai dari ROA, EPS dan BVPS tidak mengalami perubahan atau konstan, maka harga saham sebesar 1.840 .

- ROA memiliki nilai koefisien sebesar 0,043 artinya ROA memiliki pengaruh yang positif terhadap harga saham. Jika ROA meningkat 1 satuan, maka akan menaikan harga saham sebesar 0,243 satuan; atau sebaliknya.

- EPS memiliki nilai koefisien sebesar 0,603 artinya EPS memiliki pengaruh yang positif terhadap harga saham. Jika EPS meningkat 1 satuan maka akan meningkatan harga saham sebesar 0,603 satuan; atau sebaliknya.

- BVPS memiliki nilai koefisien sebesar 0,292 yang artinya BVPS memiliki pengaruh positif terhadap harga saham, jika BVPS meningkat 1 satuan maka akan 
meningkatkan harga saham sebesar 0,292 satuan; atau sebaliknya.

\section{Hasil Uji Pengaruh Simultan (F-Test)}

ANOVA atau analisis varian berfungsi menguji derajat signifikansi beberapa variabel independen terhadap variabel dependen. Pengujian menggunakan tingkat signifikansi 0,05 . Kriteria pengujian jika nilai signifikansi (Sig. F) $<0,05$ maka $\mathrm{H}_{1}$ diterima dan $\mathrm{H}_{\mathrm{o}}$ ditolak; sebaliknya jika nilai signifikansi (Sig. F) > 0,05 maka $\mathrm{H}_{1}$ ditolak dan $\mathrm{H}_{\mathrm{o}}$ diterima.

Hasil dalam Tabel 9 menyatakan nilai signifikansi (Sig. $F=0,000)<0,05$, yang berarti $\mathrm{H}_{1}$ diterima dan $\mathrm{H}_{\mathrm{o}}$ ditolak. Dengan demikian dinyatakan bahwa variabel-variabel ROA, EPS dan BVPS, secara simultan berpengaruh signifikan terhadap Harga saham.

\section{Hasil Uji Pengaruh Parsial (t-Test)}

Uji t atau uji koefisien regresi secara parsial menggunakan tingkat signifikansi 0,05 dan 2-sisi. Kriteria pengujian yang digunakan adalah apabila nilai signifikansi (Sig. $\mathrm{t})<0,05$ maka $\mathrm{H}_{1}$ diterima dan $\mathrm{H}_{\mathrm{o}}$ ditolak; sebaliknya jika nilai signifikansi (Sig. t) $>0,05$ maka $\mathrm{H}_{1}$ ditolak dan $\mathrm{H}_{\mathrm{o}}$ diterima.

Hasil dari Tabel 10 menunjukkan bahwa variabel ROA memperoleh nilai signifikansi (Sig. $\mathrm{t}=0,000)<0,05$. Hasil ini membuktikan bahwa Return on Asset (ROA) memiliki pengaruh secara parsial yang signifikan terhadap Harga saham.

Hasil dari Tabel 10 juga menunjukkan bahwa variabel EPS memperoleh nilai signifikansi (Sig. $\mathrm{t}=0,000)<0,05$. Hasil ini membuktikan bahwa Earning per Share (EPS) memiliki pengaruh secara parsial yang signifikan terhadap Harga saham.

Tabel 10 menunjukkan hasil olah data bahwa variabel BVPS memperoleh nilai signifikansi (Sig. $\mathrm{t}=0,005)<0,05$. Hasil ini membuktikan bahwa Book Value per Share (BVPS) memiliki pengaruh secara parsial yang signifikan terhadap Harga saham.

\section{Hasil Koefisien Determinasi}

Hasil analisis di dalam Tabel 11 menunjukkan nilai $R$ diperoleh sebesar 0,831 ; artinya ada korelasi antara variabel-variabel ROA, EPS dan BVPS terhadap Harga saham. Karena nilai $R$ mendekati angka 1 berarti terjadi hubungan yang erat.

Selanjutnya, dalam Tabel 11 diperoleh juga nilai $R^{2}$ sebesar 0,831 . Hal ini artinya sumbangan pengaruh dari variabel-variabel independen yang ada adalam penelitian ini terhadap variabel dependen adalah sebesar $83,1 \%$; sedangkan sisanya dipengaruhi oleh variabel-variabel lain yang tidak dimasukan dalam model penelitian ini, yaitu $16,9 \%$.

Tabel 9. Hasil Uji F

\begin{tabular}{rccccc}
\hline Model & F-hitung & F-tabel & Sig. & Standar & Keterangan \\
\hline Regresi 1 & 181,138 & $>2,69$ & 0,000 & $<0,05$ & $\begin{array}{c}\text { Berpengaruh } \\
\text { signifikan }\end{array}$ \\
\hline
\end{tabular}

Sumber: Data Sekunder Diolah, 2019

Tabel 10. Hasil Uji t

\begin{tabular}{lccccc}
\hline Variabel & t-hitung & t-tabel & Sig. & Standar & Keterangan \\
\hline ROA & 3,627 & $>1,982$ & 0,000 & $<0,05$ & $\begin{array}{c}\text { Berpengaruh } \\
\text { signifikan } \\
\text { Berpengaruh } \\
\text { signifikan }\end{array}$ \\
BVPS & 5,934 & $>1,982$ & 0,000 & $<0,05$ & $\begin{array}{c}\text { Berpengaruh } \\
\text { signifikan }\end{array}$ \\
\hline
\end{tabular}

Sumber: Data Sekunder Diolah, 2019 
Tabel 11. Hasil Koefisien Determinasi

\begin{tabular}{lcc}
\hline Adjusted R-Square & $\begin{array}{c}\text { Std. Error of the } \\
\text { Estimate }\end{array}$ & Deskripsi \\
\hline 0,831 & 0,39088 & Berpengaruh sebesar \\
& & $83,1 \%$ \\
\hline
\end{tabular}

Sumber: Data Sekunder Diolah, 2019

\section{Pembahasan}

Dalam bagian ini akan diuraikan pembahasan atas hasil-hasil yang diperoleh dalam penelitian dikaitkan dengan teori atau konsep serta hasil-hasil penelitian terdahulu.

\section{Pengaruh ROA terhadap Harga saham}

Hasil uji hipotesis ditemukan bahwa ROA berpengaruh positif terhadap Harga saham. ROA juga secara parsial memiliki pengaruh yang signifikan terhadap harga saham. Penelitian ini sejalan dengan hasil penelitian Sambelay et al. (2017) yang menemukan hasil bahwa ROA secara parsial berpengaruh positif terhadap harga saham.

Hasil ini diperoleh dikarenakan investor menilai ROA yang tinggi mengartikan bahwa perusahaan bisa melakukan manajemen dengan baik dimna aktiva yang dimiliki agar terus bertambah dengan lebih cepat. Dengan terus bertambahnya aktiva perusahaan dengan cepat, maka akan semakin besar nilai perusahaan tersebut, dan akan banyak investor pula yang akan berminat memiliki saham itu. Dengan banyaknya permintaan untuk memiliki saham tersebut, maka akan bisa meningkatkan harga saham.

\section{Pengaruh EPS terhadap Harga saham}

Berdasarkan hasil uji hipotesis diperoleh bahwa EPS berpengaruh positif terhadap harga saham. Penelitian ini sejalan dengan penelitian sebelumnya yang dilakukan oleh Wati (2018) yang menemukan hasil bahwa EPS secara parsial memiliki pengaruh yang positif dan signifikan terhadap harga saham.

Hal ini dikarenakan investor menilai EPS yang tinggi bisa mendorong pembagian deviden yang lebih besar, sehingga banyak investor yang berminat untuk membeli harga saham itu. Dengan banyaknya permintaan untuk memiliki saham tersebut, maka bisa meningkatkan harga saham.

\section{Pengaruh BVPS terhadap Harga saham}

Berdasarkan hasil uji hipotesis diketahui BVPS berpengaruh positif terhadap Harga saham. Penelitian ini sejalan dengan penelitian sebelumnya milik Sumarno dan Gunistiyo (2017) yang menemukan hasil bahwa BVPS secara parsial memiliki pengaruh positif dan signifikan terhadap harga saham.

Hasil ini dikarenakan investor menilai BVPS sebagai harga wajar saham untuk diperbandingkan dengan harga saham yang ditawarkan. Karenanya pada saat harga wajar saham tinggi maka banyak investor pula yang akan berminat memiliki saham tersebut. Dengan adanya banyak permintaan untuk memiliki saham tersebut. maka akan bisa meningkatkan harga saham.

\section{KESIMPULAN}

Berdasarkan hasil penelitian dapat disimpulkan beberapa hal. Pertama, EPS berpengaruh positif terhadap harga saham. Hal ini dikarenakan investor menilai EPS yang tinggi bisa memungkinkan pembagian deviden yang lebih besar, dengan begitu banyak investor yang berminat untuk membeli harga saham tersebut. Dengan banyaknya permintaan untuk memiliki saham tersebut, maka bisa meningkatkan harga saham; atau sebaliknya.

Kesimpulan berikutnya adalah bahwa ROA berpengaruh positif terhadap harga saham. Hal ini dikarenakan investor menilai ROA yang tinggi menunjukkan bahwa perusahaan bisa melakukan manajemen dengan baik sehingga aktiva yang dimiliki agar terus bertambah dengan lebih cepat. Dengan terus bertambahnya aktiva milik perusahaan dengan cepat, maka akan semakin besar nilai perusahaan tersebut, dan akan banyak investor pula yang akan berminat 
memiliki saham tersebut. Dengan banyaknya permintaan untuk memiliki saham tersebut, maka bisa meningkatkan harga saham.

Ketiga disimpulkan bahwa BVPS berpengaruh positif terhadap harga saham. Hal ini dikarenakan investor menilai BVPS sebagai harga wajar saham untuk diperbandingkan kepada harga saham yang ditawarkan. Karenanya, saat harga wajar saham dinilai tinggi maka banyak investor pula yang akan berminat memiliki saham tersebut. Dengan adanya banyak permintaan untuk memiliki saham itu, bisa meningkatkan harga saham; atau sebaliknya.

Dalam penelitian ini hanya memakai tiga faktor saja yang dinilai dapat mempengaruhi harga saham, dan hanya meneliti saham-saham yang memiliki tingkat likuiditas yang tinggi, Dengan alasan tersebut, penelitian selanjutnya disarankan untuk menambah variabel lain yang dipandang dapat mempengaruhi harga saham. Selain itu, dikarenakan banyaknya kejadian permainan harga saham, disarankan juga untuk membandingkan hubungan antara rasio keuangan terhadap harga saham yang memiliki derajat likuiditas yang tinggi dengan hubungan rasio keuangan terhadap harga saham yang memiliki derajat likuiditas yang rendah.

\section{DAFTAR PUSTAKA}

Arista, D. 2012. Analisis Faktor-Faktor Yang Mempengaruhi Return Saham. Jurnal Ilmu Manajemen dan Akuntansi Terapan. Vol. 3, No. 1, hal. 1-15.

Ayu, N.N. dan Sujana, I.K. 2014. Pengaruh Financial Ratio, Firm Size, dan Cash
Flow Operating terhadap Return Share. E-Jurnal Akuntansi Univeersitas Udayana. Vol. 7, No. 3.

Brigham, E.F. dan Houston, J. 2010. Dasar-

Dasar Manajemen Keuangan. Jakarta:

Salemba Empat.

Carlo, M.A. 2014. Pengaruh Return On Equity, Dividend Payout Ratio, dan Pric to Earning Ratio pada Return Saham. EJurnal Akuntansi Universitas Udayana. Vol. 7, No. 1.

Darmadji dan Fakhrudin. 2012. Pasar Modal

di Indonesia Pendekatan Tanya Jawab. Jakarta: Salemba Empat.

Fahmi, I. 2012. Analisis Laporan Keuangan. Cetakan Kedua. Bandung: CV. Alfabeta.

Fahmi, I. 2012. Pengantar Pasar Modal. Cetakan Kesatu. Bandung: CV. Alfabeta.

Halim, A. 2012. Manajemen Keuangan Bisnis. Bogor: Ghalia Indonesia.

Harahap, S.S. 2010. Analisis Kritis Laporan Keuangan. Jakarta: PT. RajaGrafindo Persada.

Sambelay, J.J., Rate, P.V. dan Baramuli, D.N. 2017. Analisis Pengaruh Profitabilitas Terhadap Harga Saham Pada Perusahaan Yang Terdaftar Di LQ45 Periode 2012-2016. Jurnal EMBA. Vol. 5, No. 2, hal. 753-761.

Wati, K. 2018. Pengaruh Kinerja Keuangan Terhadap Harga Saham Perusahaan Sub Sektor Lembaga Pembiayaan Yang Terdaftar Di Bursa Efek Indonesia Periode 2013-2015. EJournal Administrasi Bisnis. Vol. 6, No. 1, hal. 1-14. 